\title{
Analysis and Research on the Optimal Allocation of Regional Water Resources
}

\author{
$\mathrm{Xi}$ rui-chao, Gu yu-jie \\ Zhejiang Cuangchuan Engineering Consulting Co.,Ltd.,Hangzhou, Zhejiang 310020, China
}

\begin{abstract}
Starting from the basic concept of optimal allocation of water resources, taking the allocation of water resources in Tianjin as an example, the present situation of water resources in Tianjin is analyzed, and the multi-objective optimal allocation model of water resources is used to optimize the allocation of water resources. We use LINGO to solve the model, get the optimal allocation plan that meets the economic and social benefits, and put forward relevant policies and regulations, so as to provide theoretical which is basis for alleviating and solving the problem of water shortage.
\end{abstract}

\section{Introduction}

According to the WMO and UNESCO in the definitions of water resources, water resources is available source of water, the water should have sufficient quantity and the appropriate quality, and meet a specific use in a period of time. Taking the allocation of water resources in Tianjin as an example, by multi-objective optimal allocation and LINGO to solve the model, so as to provide theoretical which is basis for alleviating and solving the problem of water shortage.

\section{Water Resources Current Status in Tianjin}

First, the average annual value of surface water resources in Tianjin is 1055 million $\mathrm{m}^{3}$, the groundwater resource content is 832 million $\mathrm{m}^{3}$, the repeated calculation is 70.8 million $\mathrm{m}^{3}$, and the total water resources mean is 1816 million $\mathrm{m}^{3}$ in Tianjin ${ }^{[1]}$. Second, because of urban sewage discharge and pesticide pollution, and the annual river water volume decreasing year by year, the water self purification ability is reduced, and the water pollution of each river is serious, and the water quality is deteriorating. Third, the groundwater is overtaken seriously. There is salt water area in the south of Tianjin because that surface water resource is lack and it is explored seriously that it is difficult to restore the deep groundwater ${ }^{[2]}$.

Through the understanding of the current situation of water resources in Tianjin, the optimal allocation model of water resources in Tianjin is established, which lays the foundation for the rational allocation of regional water resources.

\section{Establishing the optimization model of water resources}

The optimal allocation of water resources is the guarantee of the sustainable utilization of water resources, and it is the basic to realize the rational exploitation and utilization of water resources ${ }^{[3]}$. It refers to the basin area, by using the theory of system engineering and optimization method, a variety of available in regional and the water sector between the optimal allocation and allocation of water resources utilization, and strive to comprehensive benefits of social and ecological economy and realize the limited water resources maximum.

\subsection{Objective Functions}

The general goal or the highest level goal of water resources system optimization is to achieve rational allocation of water resources and support the comprehensive and coordinated development of the whole society and economy. [4]. Therefore, water resource optimal allocation is a complex multi-objective decision problem.

Its objective function can be described as follows:

$$
\mathrm{M}=\max \left\{f_{1}(\mathrm{X}), f_{2}(\mathrm{X})\right\}
$$

where $\mathrm{X}$ is decision vector made up of different number and quality water resources; $f_{l}(\mathrm{X})$ and $f_{2}(\mathrm{X})$ are the social and economic benefit of water resources development and utilization.

\subsubsection{Objective 1: Economic Benefit}

It is described by the maximum region water supply net benefit:

$$
\max f_{l}(\mathrm{X})=\max \sum\left(\mathrm{B}_{\mathrm{j}}-\mathrm{C}_{\mathrm{j}}\right) \mathrm{X}_{\mathrm{j}}
$$

where $X_{j}$ is water supply volume $\left(10^{4} \mathrm{~m}^{3}\right) ; B_{j}$ is benefit coefficient (yuan/ $\mathrm{m}^{3}$ ); $\mathrm{C}_{\mathrm{j}}$ is cost benefit coefficient (yuan/ $\mathrm{m}^{3}$ ).

\footnotetext{
* Corresponding author email: happyxre@126.com
} 


\subsubsection{Objective 2: Social Benefit}

It is described by the minimum total volume of region water shortage:

$$
\max f_{2}(\mathrm{X})=-\min \sum \sum\left(\mathrm{D}_{\mathrm{i}}^{\mathrm{k}}-\sum \mathrm{x}_{\mathrm{ij}}^{\mathrm{k}}\right)
$$

where $\mathrm{D}_{j}^{k}$ is water demand volume of $j$ user in $k$ subarea $\left(10^{4} \mathrm{~m}^{3}\right) ; x_{i j}{ }^{k}$ is water supply volume $\left(10^{4} \mathrm{~m}^{3}\right)$.

\subsection{Constraint Condition}

Water supply capacity constraint of regional water supply system, water demand capacity constraint of regional water system and regional harmonious development constraint are mainly considered in the water resources optimal allocation model of Tianjin city.

\subsubsection{Regional Water Supply Capacity Constraint}

Water supply capacity constraint of regional water supply system, that means water volume that obtained by $j$ user in $k$ subarea from water source should be meet the user's water supply:

$$
\sum \mathrm{x}_{\mathrm{ij}}{ }^{\mathrm{k}} \leq \mathrm{W}_{\mathrm{i}}^{\mathrm{k}}
$$

where $\mathrm{W}_{\mathrm{i}}^{\mathrm{k}}$ is the water supply volume of $i$ water resources in $\mathrm{k}$ subarea respectively.

\subsubsection{Regional Water Demand Capacity Constraint}

Water volume that obtained by $j$ user in $k$ subarea from water source should be between the upper and lower limit of user's water demands:

$$
\begin{aligned}
& \sum \mathrm{x}_{\mathrm{ij}}{ }^{\mathrm{k}} \leq \mathrm{H}_{\mathrm{i}}^{\mathrm{k}} \\
& \sum \mathrm{x}_{\mathrm{ij}}{ }^{\mathrm{k}} \leq \mathrm{L}_{\mathrm{i}}{ }^{\mathrm{k}}
\end{aligned}
$$

where $\mathrm{H}_{j}^{k}$ and $\mathrm{L}_{j}^{k}$ are the upper and lower limit of water demand volume of $j$ user in $k$ subarea respectively.

\subsubsection{Variable Non-negative Constraint}

The variable non-negative constraint, which means that the supply water are non-negative, and as following:

$$
x_{i j}{ }^{k} \geq 0
$$

\subsection{Model Establishment}

The whole water resources optimal allocation model of Tianjin city can be obtained to combine the objective functions with the constraint conditions.

$$
\begin{array}{ll}
\text { obj : M(X) } & =\text { opt }\left\{f_{1}(x), f_{2}(x)\right\} \\
\max f_{1}(X) & =\max \sum_{j}\left(B_{j}-C_{j}\right) X_{j} \\
\max f_{2}(X) & =-\min \sum_{k=1}^{K} \sum_{j}\left(D_{j}^{k}-\sum_{i} x_{i j}^{k}\right) \\
\text { s.t. } \quad \sum_{j=1}^{J(k)} x_{i j}^{k} \leq W_{i}^{k} \\
L_{j}^{k} \leq \sum_{i=1}^{r(k)} x_{i j}^{k} \leq H_{j}^{k} \\
x_{i j}^{k} \geq 0
\end{array}
$$

where $\mathrm{X}$ is decision vector; $f_{l}(\mathrm{X})$ and $f_{2}(\mathrm{X})$ are the social and economic benefit of water resources development and utilization; $\mathrm{D}_{j}^{k}$ is water demand volume of $j$ user in $k$ sub area $\left(10^{4} \mathrm{~m}^{3}\right) ; \mathrm{W}_{\mathrm{i}}^{\mathrm{k}}$ is the water supply volume of $i$ water resources in $\mathrm{k}$ sub area respectively.

\section{Solving Model}

Water resources optimization model of Tianjin city is multi-objective optimal model, in order to solve model, we use the optimal solver of LINGO.

\subsection{The upper and lower limits of Living Water Demand}

Considering the characteristics of domestic water, the upper and lower limits are taken as the water requirement.

$$
H_{1}^{k}=L_{1}^{k}=D_{1}^{k} \quad(\mathrm{k}=1,2,3)
$$

where $\mathrm{H}_{1}{ }^{k}$ and $\mathrm{L}_{1}{ }^{k}$ are the upper and lower limit of water demand volume respectively; $\mathrm{D}_{1}{ }^{k}$ is the life water volume of $k$ subarea in planning year. Thus, the upper and lower limit of life water of Beisan river mountain area is $\mathrm{H}_{1}{ }^{1}=$ $\mathrm{L}_{1}{ }^{1}=\mathrm{H}_{1}{ }^{1}=64$ million $\mathrm{m}^{3}$, and the upper and lower limit of life water of Beisi river plain is $\mathrm{H}_{1}^{2}=\mathrm{L}_{1}^{2}=\mathrm{D}_{1}^{2}=534$ million $\mathrm{m}^{3}$, and meanwhile, the upper and lower limit of life water of Diandongqingnan plain is $\mathrm{H}_{1}{ }^{3}=\mathrm{L}_{1}{ }^{3}=\mathrm{H}_{1}{ }^{3}=453$ million $\mathrm{m}^{3}$.

\subsection{Upper and Lower Limits of Industrial Water Demand}

Considering the characteristic of industrial water demand, the upper and lower limits of industrial water demand volume is calculated by the following formula:

$$
\left\{\begin{array}{l}
\mathrm{H}_{2}{ }^{\mathrm{k}}=\mathrm{D}_{2}{ }^{\mathrm{k}} \\
\mathrm{L}_{2}{ }^{\mathrm{k}}=0.8 \mathrm{D}_{2}^{\mathrm{k}}
\end{array}\right.
$$

where $\mathrm{H}_{2}{ }^{k}$ and $\mathrm{L}_{2}{ }^{k}$ are the upper and lower limit of life water consumption respectively; $\mathrm{D}_{2}{ }^{k}$ is the industrial water demand volume of $k$ subarea in planning year.

Therefore, the upper limit of industrial water consumption in Beisan river mountain area is $\mathrm{H}_{2}{ }^{1}=0.0720$ billion $\mathrm{m}^{3}$, and the lower limit is $\mathrm{L}_{2}{ }^{1}=57.6$ million $\mathrm{m}^{3}$; the upper limit of industrial water consumption in Beisi river plain is $\mathrm{H}_{2}^{2}=600$ million $\mathrm{m}^{3}$, and the lower limit is $\mathrm{L}_{2}{ }^{2}=480$ million $\mathrm{m}^{3}$; the upper limit of industrial water consumption in Diandongqingnan plain is $\mathrm{H}_{2}{ }^{3}=508$ million $\mathrm{m}^{3}$, and the lower limit is $\mathrm{L}_{2}{ }^{3}=406$ million $\mathrm{m}^{3}$.

\subsection{Upper and Lower Limits of Agricultural Irrigation Water Demand}

The upper and lower limits of agricultural irrigation water demand should be decided by effective irrigation area, guaranteed irrigation area and comprehensive irrigation quota:

$$
\left\{\begin{array}{l}
\mathrm{H}_{3}{ }^{\mathrm{k}}=\mathrm{S}_{\mathrm{yx}}{ }^{\mathrm{k}} \times \mathrm{G}^{\mathrm{k}}=\mathrm{D}_{3}{ }^{\mathrm{k}} \\
\mathrm{L}_{3}{ }^{\mathrm{k}}=\mathrm{S}_{\mathrm{bx}}{ }^{\mathrm{k}} \times \mathrm{G}^{\mathrm{k}} \quad(\mathrm{k}=1,2,3)
\end{array}\right.
$$

where $\mathrm{H}_{3}{ }^{k}$ and are the upper and lower limit of life water consumption respectively; $\mathrm{S}_{y x}{ }^{k}$ and $\mathrm{S}_{b z}{ }^{k}$ are effective irrigation area and guaranteed irrigation area of $\mathrm{k}$ subarea; $\mathrm{D}_{3}{ }^{k}$ is the industrial water demand volume of $\mathrm{k}$ subarea in planning year. 
Therefore, the upper limit of agricultural irrigation water demand volume in Beisan river mountain area is $\mathrm{H}_{3}{ }^{1}=156$ million $\mathrm{m}^{3}$, and the lower limit is $\mathrm{L}_{3}{ }^{1}=140$ million $\mathrm{m}^{3}$; the upper limit of agricultural irrigation water demand volume in Beisi river plain is $\mathrm{H}_{3}{ }^{2}=1300$ million $\mathrm{m}^{3}$, and the lower limit is $\mathrm{L}_{3}{ }^{2}=1157$ million $\mathrm{m}^{3}$; the upper limit of agricultural irrigation water demand volume in Diandongqingnan plain is $\mathrm{H}_{3}{ }^{3}=1102$ million $\mathrm{m}^{3}$, and the lower limit is $\mathrm{L}_{3}{ }^{3}=992$ million $\mathrm{m}^{3}$.

\subsection{Solving model Based on LINGO}

New model can be obtained by combining goal programming in optimization solver of LINGO with the above conditions and inducing into original model. And we may get the data from table 1 to table 3, the result from table 4.The LINGO model is as follows:

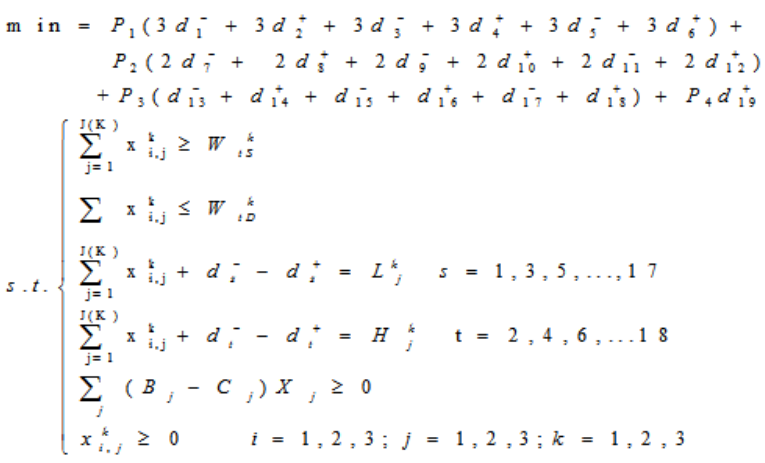

It can be shown that water distribution principles of mountains Zone of Beisan River, Plain of Beisi River and Diandongqingnan are satisfied basically by the above calculation and analysis. Life water requirement should be met firstly, and surface water should be used to supply water at the beginning, and shadow groundwater follows, and at last it is the other water sources(include wastewater reuse and cross border water resources etc.); according to water deficiencies the shortage of water is serious in Diandongqingnan plain that local water source is 224 million $\mathrm{m}^{3}$ which cannot meet local water demand of 1851 million $\mathrm{m}^{3}$ and it needs to divert a large scale of other sources to satisfy the demand water of normal life, industrial and agricultural water.

Table 1. The annual water supply scale of 2030 level in Tianjin under the condition of $75 \%$ guarantee rate $\left(10^{8} \mathrm{~m}^{3}\right)$

\begin{tabular}{|c|c|c|c|c|}
\hline Subarea & $\begin{array}{c}\text { Surface } \\
\text { water } \\
\text { resource }\end{array}$ & $\begin{array}{c}\text { Groundwate } \\
\text { r resource }\end{array}$ & $\begin{array}{c}\text { Other } \\
\text { water } \\
\text { volume }\end{array}$ & Total \\
\hline $\begin{array}{c}\text { Beisan river } \\
\text { mountain area }\end{array}$ & 1.00 & 0.34 & 2.13 & 3.47 \\
\hline $\begin{array}{c}\text { Beisi river } \\
\text { plain }\end{array}$ & 2.30 & 3.79 & 7.43 & 13.52 \\
\hline $\begin{array}{c}\text { Diandongqing } \\
\text { nan plain }\end{array}$ & 1.87 & 0.37 & 0.00 & 2.24 \\
\hline Total & 5.17 & 4.50 & 9.56 & 19.23 \\
\hline
\end{tabular}

Table 2. Water demand table of Tianjin in 2030 under $75 \%$ guarantee rate $\left(10^{8} \mathrm{~m}^{3}\right)$

\begin{tabular}{|c|c|c|c|c|}
\hline Subarea & $\begin{array}{c}\text { Life } \\
\text { water }\end{array}$ & $\begin{array}{c}\text { Industrial } \\
\text { water }\end{array}$ & $\begin{array}{c}\text { Agriculture } \\
\text { water }\end{array}$ & Total \\
\hline $\begin{array}{c}\text { Beisan river } \\
\text { mountain area }\end{array}$ & 0.64 & 0.72 & 1.56 & 2.92 \\
\hline Beisi river plain & 5.34 & 6.00 & 13.00 & 24.34 \\
\hline $\begin{array}{c}\text { Diandongqingna } \\
\text { n plain }\end{array}$ & 4.53 & 5.08 & 11.02 & 20.63 \\
\hline Total & 10.51 & 11.80 & 25.58 & 47.89 \\
\hline
\end{tabular}

Table 3.Water resources benefit and cost table in Tianjin

\begin{tabular}{|c|c|c|}
\hline Subarea & $\begin{array}{c}\text { Benefit } \\
\left(\text { Yuan } / \mathrm{m}^{3}\right)\end{array}$ & Cost $\left(\right.$ Yuan $\left./ \mathrm{m}^{3}\right)$ \\
\hline Life water & 500 & 2.38 \\
\hline Industrial water & 280 & 3.78 \\
\hline Agriculture water & 1 & 0.30 \\
\hline
\end{tabular}

Table 4. The results of optimal allocation of water resources in Tianjin under the $75 \%$ guarantee rate in $2030\left(10^{8} \mathrm{~m}^{3}\right)$

\begin{tabular}{|c|c|c|c|c|c|c|c|c|c|}
\hline Subarea & \multicolumn{3}{|c|}{ Life water } & \multicolumn{3}{c|}{$\begin{array}{l}\text { Industrial } \\
\text { water }\end{array}$} & \multicolumn{3}{c|}{$\begin{array}{c}\text { ggricultural } \\
\text { water }\end{array}$} \\
\hline Beisan & $\mathrm{X}_{1}$ & $\mathrm{X}_{1}$ & $\mathrm{X}_{1}$ & $\mathrm{X}_{1}$ & $\mathrm{X}_{1}$ & $\mathrm{X}_{1}$ & $\mathrm{X}_{1}$ & $\mathrm{X}_{1}$ & $\mathrm{X}_{1}$ \\
river & 11 & 12 & 13 & 21 & 22 & 23 & 31 & 32 & 33 \\
\cline { 2 - 12 } mountain & 0. & 0. & 0. & 0. & 0. & 0. & 0. & 0. & 1. \\
area & 30 & 34 & 00 & 15 & 00 & 57 & 00 & 00 & 56 \\
\hline Total & \multicolumn{3}{|c|}{0.64} & \multicolumn{3}{c|}{0.72} & \multicolumn{3}{c|}{1.56} \\
\hline Beisi & $\mathrm{X}_{2}$ & $\mathrm{X}_{2}$ & $\mathrm{X}_{2}$ & $\mathrm{X}_{2}$ & $\mathrm{X}_{2}$ & $\mathrm{X}_{2}$ & $\mathrm{X}_{2}$ & $\mathrm{X}_{2}$ & $\mathrm{X}_{2}$ \\
river & 11 & 12 & 13 & 21 & 22 & 23 & 31 & 32 & 33 \\
\cline { 2 - 11 } plain & 5. & 0. & 0. & 4. & 0. & 0. & 0. & 3. & 7. \\
& 34 & 00 & 00 & 80 & 00 & 00 & 35 & 79 & 43 \\
\hline Total & \multicolumn{3}{|c|}{5.34} & \multicolumn{5}{c|}{4.80} & \multicolumn{3}{c|}{11.57} \\
\hline Diandon & $\mathrm{X}_{3}$ & $\mathrm{X}_{3}$ & $\mathrm{X}_{3}$ & $\mathrm{X}_{3}$ & $\mathrm{X}_{3}$ & $\mathrm{X}_{3}$ & $\mathrm{X}_{3}$ & $\mathrm{X}_{3}$ & $\mathrm{X}_{3}$ \\
gqingnan & 11 & 12 & 13 & 21 & 22 & 23 & 31 & 32 & 33 \\
\cline { 2 - 10 } plain & 1. & 0. & 3. & 0. & 0. & 3. & 0. & 0. & 9. \\
& 37 & 00 & 16 & 50 & 00 & 56 & 00 & 37 & 55 \\
\hline Total & \multicolumn{3}{|c|}{4.53} & \multicolumn{3}{c|}{4.06} & \multicolumn{5}{c|}{9.92} \\
\hline
\end{tabular}

Note $: \mathrm{X}_{\mathrm{ijk}}$ is the water volume used for $j$ user of $i$ water source in $k$ sub area, where i represents the subarea; $\mathrm{j}$ represents the user, $\mathrm{k}$ represents the water source

\section{Measures for optimal allocation of water resources}

\subsection{Rational allocation of water resources}

The available water resources distribution principle is tapping and saving ${ }^{[5]}$. The following measures should be taken to rationally optimize the allocation of water resources: (1) Control of surface water by means of government macro-control. (2) The exploitation of deep groundwater can be reduced so that it can be used as a backup water source or emergency water source as far as possible. (3) Diversion water with a comprehensive 
means.

\subsection{Reinforcement of Water Resources Protection}

To ensure the safety of water resources in China, water pollution should be prevented from the source, and the ecological protection of the water body of the reservoir, river and canal system. The specific measures are as follows: (1) To combine civil air defense with technological prevention. (2) Increasing publicity and enforcement of water pollution prevention and treatment.

\subsection{Improving the efficiency and efficiency of water resources utilization}

China's water resources are seriously short. Strengthening the rational allocation of water resources is the objective requirement for the sustainable development of the economic society. Water saving is also the top priority in the allocation of water resources. Therefore, it is imperative to improve the efficiency and benefit of water resources utilization.

\section{Conclusions}

China's water resources are seriously short, and it is resources water shortage and its exploitation and utilization ratio is large, and the water pollution is grave, meanwhile groundwater is explored excessively and water quality standard is exceeded. Based on this situation, the water resources of Tianjin city as an example, the model of multi-objective optimization is established economic and social benefits as the goal, through the LINGO optimization method of goal programming solver to solve the model, the first to meet the living water, then the second to content the industrial water, finally meet the principle of optimization scheme of water supply of agricultural water. Combined with the shortage of water resources in our country, we must not rely on water saving alone, we should take the policy measures that both open source and throttle should be equally emphasized. At the same time, we should pay attention to preventing and controlling water pollution and strengthening the protection of water resources.

\section{References}

1. Zhang Kai. About Tianjin water resources value and water value research. College of management of Tianjin university.2006,1.

2. Yao Yutian. The optimal allocation of water resources and water save research of Tianjin. The construction technology of Tianjin. 1996,4.

3. Han Haiyan, Yu Sujun. Study on the optimal allocation of water resources in Rong County based on Multi-objective optimization model. The agricultural science of Anhui. 2010,38 (19) :10200 10202.

4. Zhang Chengfeng. Study on optimal allocation of Yulin water resources based on genetic algorithms. Thesis for Master Degree Northwest A \&F University .2008:21 29 .

5. Zhou Shumei, Jia Liye, Zhou Jinda. Some kinds of suggests of Tianjin City about optimal allocation of water resources and water saving. Hydrology. 2009, 29 (1) :36 37 